\title{
Ensino da língua portuguesa no ensino médio a partir da pedagogia de projetos
}

\author{
Sinval Martins de Sousa Filho* \\ Maria de Fátima Furtado Baú**
}

\begin{abstract}
Resumo
A partir da descrição e análise iniciais de um projeto intitulado Projeto Minha Autoria, desenvolvido em uma turma de segundo ano do Ensino Médio de uma escola pública da região Oeste de Goiânia, objetivamos descrever e analisar aspectos preliminares da proposta de ensino intitulada Pedagogia de Projetos aplicada ao estudo do gênero discursivo conto para o desenvolvimento do curso de língua portuguesa numa escola da rede estadual de ensino do Estado de Goiás. Serviram de orientação ao estudo conceitos tais como Pedagogia de Projetos, dialogismo, educação bancária, educação problematizadora, linguagem, oralidade/escuta, leitura, escrita, análise linguística, gênero do discurso, os quais foram evidenciados dentro de uma abordagem dialógica, pautada nos estudos de Freire, Bakhtin e Vigotski. A metodologia utilizada foi a pesquisa-ação colaborativa. Os dados que serviram de referência para as considerações foram coletados durante a realização do Projeto Minha Autoria, o qual foi realizado no quarto bimestre de 2013. A análise demonstra que os alunos retomam as orientações dadas pelas professoras aos grupos durante as tarefas e, por isso, dependem da mediação efetiva do docente. Também, fica evidente que a intervenção das professoras durante o processo de preparação, bem como no momento da produção verbal - em suas diversas modalidades - é necessária para que os objetivos sejam atingidos.
\end{abstract}

Palavras-chave: Pedagogia de projetos. Gênero conto. Ensino e aprendizagem. Desenvolvimento linguístico.

\section{Introdução}

A educação está sempre em desenvolvimento a partir de nuances diversas e dinâmicas e estas provocam vários questionamentos, planos e algumas realizações no que se refere à prática educativa, apesar de existirem grandes resistências à ideia de mudanças e inovações. Essas resistências ocorrem não só por parte de educadores, mas também por ações de gestores, de alunos e pais, ou seja, de toda a população envolvida no processo de escolarização ou de educação escolar brasileira.

* Universidade Federal de Goiás (UFG).

** Mestranda em Estudos Linguísticos na Universidade Federal de Goiás (UFG). 
Nas muitas proposições para as mudanças, alguns educadores propuseram uma pedagogia que desse mais sentido aos conteúdos estudados em sala de aula. Uma intervenção didática que mostrasse os benefícios que os trabalhos com Pedagogia de Projetos podem trazer aos alunos e professores. Conforme afirma Hernández (1998, p. 67), ao se trabalhar com projetos, “o que se pretende é que o aluno não sinta diferença entre a vida exterior e a vida escolar". É importante que o ensino tenha mais significado para o aluno, de forma que relacione os conhecimentos adquiridos em sala com aqueles que fazem parte do seu contexto sociocultural.

A proposta de ensino por meio da Pedagogia de Projetos não é nova, uma vez que tem sua origem no início do século $\mathrm{XX}$, na obra de grandes pedagogos, como, por exemplo, Decroly, o qual defende a proposição dos centros de interesse; Kerchensteiner, que defende a ideia de trabalho em cooperação; Dewey, com a ideia do problema e do aprender fazendo; Freinet, com a proposição de efetivação de cooperativas, do texto livre, da imprensa e da correspondência escolar (cf. MICOTTI, 2009). As propostas desses estudiosos foram introduzidas e divulgadas no Brasil principalmente por Anísio Teixeira e Lourenço Filho (DUARTE, 1971).

A proposta da Pedagogia de Projetos busca novas formas de ensinar dirigidas à realidade dos alunos, fazendo com que estes aprendam de forma autônoma e sejam sujeitos da sua própria aprendizagem, juntando teoria e prática (LEITE, 1996). Ainda, para Hernández (1998) e Hernández e Ventura (1999), ela é uma proposta pedagógica centrada na necessidade de resolver um problema social detectado no âmbito escolar e uma das principais propostas desses educadores consiste na reorganização do currículo por projetos, pois assim o aluno passa a ser o sujeito do processo de ensino/aprendizagem, já que o professor deixa de ser o "transmissor de conteúdos" para se transformar em um pesquisador.

Para Leite (1996), o trabalho com projetos busca (re)significar o espaço escolar, tornando-o um ambiente no qual aprender deixa de ser um simples ato de memorização e ensinar não significa mais repassar conteúdos prontos e acabados, pois se entende que a educação é a responsável pela formação, não só cognitiva, mas também social das pessoas.

No que se refere ao ensino de Língua Portuguesa, que é o foco principal deste trabalho, vemos que o processo de ensino/aprendizagem dessa disciplina se dá pela fragmentação e descontextualização da língua/linguagem. E essa forma de conduzir o processo ainda continua a se repetir na maioria das escolas. Para Antunes (2003), as práticas, no que se refere ao estudo da Língua Portuguesa, continuam 
inadequadas e irrelevantes, não condizem com as mais recentes concepções de língua, muito menos com os objetivos mais amplos que legitimamente se pode pretender para o seu ensino. Antunes (2003) aponta também que a prática pedagógica dos professores de Língua Portuguesa ainda continua numa perspectiva reducionista do estudo da palavra e da frase descontextualizadas, deixando de lado uma compreensão mais relevante da linguagem, que é promover a interação dos indivíduos.

Este texto descreve e analisa os resultados do ensino de língua portuguesa a partir da Pedagogia de Projetos, resultados estes obtidos através da participação e da colaboração direta entre o pesquisador e um professor colaborador e os alunos do Ensino Médio de uma escola da Rede Pública Estadual, situada em Goiânia.

Os procedimentos metodológicos utilizados para coleta de dados se caracterizaram por: 1) entrevista semiestruturada, questionário (questões abertas), observação participante (diário de campo) e análise documental (textos produzidos e organizados pelos alunos).

Para desenvolver o projeto, centramo-nos nas competências discursivas e comunicativas dos alunos.

As propostas de ensino atuais, de certa forma, segundo Antunes (2003), já estão legitimadas nas instituições governamentais, em todos os níveis, apresentando ações a favor de uma escola mais formadora e eficiente. Um exemplo citado pela referida autora são os Parâmetros Curriculares Nacionais (BRASIL, 1999), que trazem em suas concepções teóricas a dimensão interacional e discursiva da língua, além de definir que o domínio pleno dessa língua é uma das condições para a participação crítica do indivíduo em seu meio social.

Ainda, afirmamos que a Lei de Diretrizes e Bases da Educação (BRASIL, 1996), os Parâmetros Curriculares Nacionais (BRASIL, 1999) e as Orientações Curriculares para o Ensino Médio (BRASIL, 2006) também defendem essa ideia, já que nesses documentos consta que a escola tem a responsabilidade social de formar cidadãos críticos e conscientes de seu papel na sociedade. E não só de repassar conteúdos aos alunos, como se esses fossem meros receptores passivos de tudo que o professor, detentor do conhecimento, tem para lhes transmitir (FREIRE, 1987).

Nesse sentido, a Pedagogia de Projetos se mostra uma proposta eficiente para transformar essa realidade e fazer do ensino de Língua Portuguesa uma fonte de construção social e formação crítica e reflexiva dos alunos como nos indica Hernández (2000). 
Observa-se que, em trabalhos realizados na perspectiva de Pedagogia de Projetos, o professor deixa de ser o transmissor do conhecimento e passa a se portar como o mediador entre o conhecimento e o aluno. Dessa forma, deixa de ser a única fonte de saber, pois o aluno também participa ativamente do processo de construção do conhecimento.

Diante do exposto, acreditamos que a escola deve criar situações de ensino e aprendizagem nas quais a relevância dos seus conteúdos culturais selecionados em um projeto curricular possa promover interação, diálogo e proporcionar processos de reconstrução, acrescentando novas experiências sociopsicológicas às que já existem nas estruturas cognitivas dos estudantes. Acreditamos na relevância desta investigação, uma vez que a Pedagogia de Projetos possibilita trabalhar o ensino da Língua Portuguesa de forma mais contextualizada, ou seja, que tenha mais significado para os alunos, uma vez que propõe uma maior participação deles, objetivando motivá-los a buscar o conhecimento de forma autônoma por meio de investigações que eles mesmos devem propor, desenvolver e construir, com a orientação e a mediação do professor.

Em conformidade com os conceitos apresentados, desenvolvemos um trabalho em que o objetivo geral foi a verificação de como a Pedagogia de Projetos pode contribuir no processo de ensino/aprendizagem da Língua Portuguesa no Ensino Médio no que refere à leitura e escrita; à oralidade e escuta e análise da língua. E os objetivos específicos foram: i) a observação de como os Projetos podem contribuir com o estudo da Língua Portuguesa no que refere à leitura e escrita; à oralidade e escuta e análise da língua; e ii) a avaliação de como se dá a atuação do professor no ensino da língua portuguesa, bem como a participação dos alunos durante o desenvolvimento do(s) Projeto(s).

Na próxima seção, apresentamos aspectos relevantes da teoria adotada no trabalho. Na seção 3, analisamos algumas das atividades produzidas no decorrer do período de duração da abordagem da Pedagogia de Projetos para o ensino de Língua Portuguesa.

\section{O ensino da língua portuguesa por meio da Pedagogia de Projetos}

A partir da descrição e análise de um projeto intitulado Projeto Minha Autoria, desenvolvido em uma turma de segundo ano do Ensino Médio de uma escola pública da região Oeste de Goiânia, objetivamos descrever e analisar a proposta de 
ensino Pedagogia de Projetos aplicada ao estudo do gênero discursivo conto para o desenvolvimento do curso de língua portuguesa numa escola da rede estadual de ensino do Estado de Goiás. Como apontamos na seção anterior, serviram de orientação ao estudo conceitos tais como Pedagogia de Projetos, dialogismo, educação bancária, educação problematizadora, linguagem, oralidade/escuta, leitura, escrita, análise linguística, gênero do discurso, os quais foram evidenciados dentro de uma abordagem dialógica, pautada nos estudos de Freire, Bakhtin e Vigotski e seus desdobramentos nas atuais pesquisas na área de educação e linguagem, representadas, sobretudo, nos estudos de Hérnandez, Micotti, Alvarez, Jolibert e outros da educação, bem como nos estudos de Geraldi, Brait e outros expoentes da linguística brasileira.

Centramo-nos numa pesquisa a partir do que a Pedagogia de Projetos pode oferecer num processo de educação escolar. Esse desenvolvimento decorre do entendimento que temos de que, para avançarmos e até mesmo ultrapassarmos a prática de transmissão de conteúdos, precisamos realizar um trabalho que envolva os alunos de forma efetiva em sua aprendizagem.

Acreditamos que o trabalho por meio da Pedagogia de Projetos é uma estratégia bastante eficaz porque cumpre com os pressupostos do ensino interacionista, o que, segundo Hernández (1998), agencia a aprendizagem a partir da interação entre as pessoas e essa característica a coliga com a teoria dialógica do teórico brasileiro Paulo Freire, aos conceitos de Interação de L. S. Vigotski e de polifonia de Mikhail Bakhtin, conceitos que nos remetem ao que Freire (1987) chama de dialogismo.

Os temas geradores de Freire (1987) nascem de uma proposta de educação que se assemelha muito à proposta de trabalhos realizados por meio da Pedagogia de Projetos. Ambas as propostas defendem uma educação pautada no diálogo, em que educador e educando constroem seus conhecimentos juntos e por meio do diálogo. O que, segundo Freire (1987), se opõe à educação bancária, em que o aluno é passivo e recebe tudo pronto, não havendo, assim, um verdadeiro aprendizado, já que é uma educação muda. Assim sendo, para esse teórico, só há um verdadeiro aprendizado quando esse é construído por meio de um processo dialógico, o qual ele chama de educação dialógica e/ou problematizadora.

Assim como Bakhtin (2004), Vigotski (2007) e Freire (1987), compreendemos a linguagem a partir das interações, ou seja, dentro de uma concepção discursiva dialógica, pois a linguagem é concebida de um ponto de vista histórico, cultural e social, já que esta é desenvolvida por meio de trocas, de experiências, pelo compartilhamento entre os indivíduos. 
Reiteramos essa ideia a partir dos pressupostos de Vigotski (2008), que afirma ser a linguagem constituída historicamente, bem como pela cultura, pois para esse teórico a linguagem é determinada "por um processo sócio-histórico" e " não é uma forma de comportamento natural e inata" (VIGOTSKI, 2008, p. 63).

Freire (1987) concebe a linguagem como um fenômeno sócio-histórico também, mas esta para esse teórico constitui-se em um terreno tanto de dominação quanto de possibilidades, já que tem um papel ativo na construção da experiência, da organização, bem como da legitimação das práticas sociais disponíveis aos vários grupos da sociedade.

Bakhtin (2003) concebe a linguagem enquanto processo, sendo esta vista como inacabada, pois, conforme afirma Machado (2013), o inacabamento é o princípio a partir do qual é possível considerar a poiesis do dialogismo como campo conceitual bakhtiniano. E a enunciação, para Bakhtin (2003), é a força motriz essencial da língua, já que, para ele, a língua constitui-se numa evolução contínua que se efetiva na e pela interação verbal dos interlocutores, ou seja, a linguagem é um processo criativo, que se materializa nas enunciações. Essa noção pode ser mais bem entendida quando Bakhtin (2003, p. 274-275) afirma que

o discurso só pode existir de fato na forma de enunciações concretas de determinados falantes, sujeitos do discurso. O discurso sempre está fundido em forma de enunciação pertencente a um determinado sujeito do discurso, e fora dessa forma não pode existir. Por mais diferentes que sejam as enunciações pelo seu volume, e pelo conteúdo, pela construção composicional, elas possuem como unidades da comunicação discursiva peculiaridades estruturais comuns, e antes de tudo limites absolutamente precisos.

Nota-se que nessa perspectiva de linguagem defendida por Bakhtin (2003), ou seja, por enunciações, ela é dialógica por natureza. Assim sendo, percebe-se que, para ele, a alteridade define o ser humano, já que o outro é imprescindível para a sua concepção individual. Portanto, é impossível pensar o homem fora das relações que o ligam ao outro (BAKHTIN, 2003).

E é partindo desse contexto que se deve constituir a relação de sala de aula. Visto que

é preciso que se tenha presente que toda e qualquer metodologia de ensino articula uma opção política - que envolve uma teoria de compreensão e interpretação da realidade - com os mecanismos 
utilizados em sala de aula. Assim, os conteúdos, o enfoque que se dá a eles, as estratégias de trabalho com os alunos, a bibliografia utilizada, o sistema de avaliação, o relacionamento com os alunos, tudo corresponderá, nas nossas atividades concretas de sala de aula, ao caminho por que optamos (GERALDI, 2004, p. 40).

Geraldi ainda acrescenta que quando se fala em ensino, os educadores se esquecem de uma questão prévia "para que ensinamos o que ensinamos?" (GERALDI, 2004, p. 40), e sua correlata: para que os alunos aprendem e o que eles aprendem? Segundo esse autor, essas questões são esquecidas em detrimento de discussões sobre como ensinar, quando ensinar, o que ensinar, entre outras questões. Ele considera, no entanto, que a resposta ao "para quê" é que dará efetivamente as diretrizes básicas das respostas. E isso, segundo ele, envolve tanto uma concepção de linguagem, quanto uma postura relativamente à educação, uma vez que, para ele, uma e outra se fazem presentes na articulação metodológica.

Quanto às concepções de linguagem, Geraldi (2004, p. 41) aponta as três concepções mais utilizadas/conhecidas, primeiro a linguagem como expressão do pensamento. Essa concepção ilumina, primeiramente, os estudos tradicionais. Se concebermos a linguagem como tal, somos levados à afirmação - corrente - de que pessoas que não conseguem se expressar não pensam. A outra concepção vê a linguagem como instrumento de comunicação. Essa concepção está ligada à teoria da comunicação e vê a língua como código (conjunto de signos que se combinam segundo regras) capaz de transmitir ao receptor uma mensagem. Em livros didáticos, é a concepção confessada nas instruções ao educador, nas introduções, nos títulos, embora, em geral, seja abandonada nos exercícios gramaticais. E, por último, a concepção de linguagem como uma forma de interação, pois mais do que possibilitar uma transmissão de informações de um emissor a um receptor, a linguagem é vista como um lugar de interação humana. Por meio dela, o sujeito que fala pratica ações que não conseguiria levar a cabo a não ser falando. Com ela, o falante age sobre o ouvinte, constituindo compromissos e vínculos que não preexistiam à fala.

Para Geraldi (2004, p. 41), essas três concepções de linguagem correspondem às três grandes correntes dos estudos linguísticos, que são a gramática tradicional, o estruturalismo e o transformacionalismo e a linguística da enunciação.

Nessas três correntes, o objetivo é descrever o funcionamento da linguagem/ língua. Já o objetivo das aulas de língua portuguesa deve ser o de oportunizar 
aos alunos o domínio dos vários dialetos da língua, inclusive o padrão. Porém, segundo Geraldi (2004, p. 45), existe outra questão a ser observada: "a dicotomia entre ensino da língua e ensino da metalinguagem”. Ou seja, a opção de um ensino da língua considerando as relações humanas que ela perpassa (concebendo a linguagem como lugar de um processo de interação), a partir da perspectiva de que na escola se pode oportunizar o domínio de mais outra forma de expressão, exige que reconsideremos "o que" vamos ensinar, já que tal opção representa parte da resposta do "para que" ensinamos (GERALDI, 2004).

Nessa perspectiva de ensino da língua portuguesa, é necessário que haja mudanças de postura da escola, dos professores, não apenas em relação às técnicas, aos métodos empregados em sala. Mas, principalmente, um "novo conteúdo" (GERALDI, 2004).

Observa-se que em trabalhos realizados por meio da proposta de Pedagogia de Projetos favorece-se o ensino da língua portuguesa nessa perspectiva, já que, segundo Jolibert (2009, p. 21), um projeto abre, de fato, possibilidades infinitas de prática da linguagem.

Num ensino pautado pela Pedagogia de Projetos, os alunos têm direito à palavra e, por isso, se constituem sujeitos. $\mathrm{O}$ estudante tem estratégias para realizar suas produções de texto e o professor passa ser o mediador, facilitador, aquele que direciona o processo de ensino/aprendizagem. $\mathrm{O}$ aluno também tem para quem dizer, não mais só o professor, mas outros interlocutores escolhidos no processo de produção da escrita. Além disso, o aluno faz parte do processo de negociação, não há imposição por parte do professor. $\mathrm{O}$ respeito a esses fatores é o princípio básico para o estabelecimento de um contexto interacionista na leitura e escrita.

De acordo com o OCNEM, (BRASIL, 2006, p. 18),

o ensino médio deve atuar de forma que garanta ao estudante a preparação básica para o prosseguimento dos estudos, para a inserção no mundo do trabalho e para o exercício cotidiano da cidadania, em sintonia com as necessidades político-sociais de seu tempo.

Pode-se dizer que a proposta de ensino da Pedagogia de Projetos está em consonância com o que se propõe para o Ensino Médio nos documentos oficiais, uma vez que esses objetivos podem ser incorporados por meio dessa proposta de trabalho. 
Sabe-se que o ensino nessa perspectiva de trabalho busca aproximar-se da realidade do aluno de modo significativo. Além disso, essa proposta proporciona a interação entre os alunos, e deles com o professor, durante as aulas, nos momentos de leitura e produção textual.

A seguir, apresentamos análises de algumas das atividades desenvolvidas durante nossas intervenções, as quais se basearam na Pedagogia de Projetos.

\section{Análise dos dados: resultados parciais}

A análise sobre o ensino da língua portuguesa por meio da proposta de ensino Pedagogia de Projetos que procuramos desenvolver está baseada nos argumentos teóricos que apresentamos anteriormente. Dessa forma, neste trabalho, focamos os estudos sobre o ensino da Língua Portuguesa por meio da Pedagogia de Projetos e, portanto, intervenções com base em teorias dialógicas/dialéticas. Exploramos nas aulas o gênero discursivo conto.

Assim, nesta seção, mostramos o desenvolvimento e os resultados de algumas atividades de práticas de leitura, interpretação e produção de texto, de oralidade e escuta, análise da língua e as percepções dos alunos envolvidos.

Por termos consciência de que o processo educativo só ocorre de forma eficaz quando está pautado no diálogo, é que, antes de iniciarmos o projeto referido, realizamos a exposição das atividades que seriam realizadas ao longo do desenvolvimento das intervenções. Na ocasião, os alunos tiveram a oportunidade de expor seus pensamentos, sugerir alterações, enfim, das participações dos alunos poderíamos até mesmo refazer todo o projeto.

Cientes do que afirmamos e com o intuito de instaurar um novo tipo de aula, procuramos dar voz aos alunos e percebemos que eles gostaram de expor suas ideias, de dar suas sugestões, enfim de ser ouvidos. Quando eles falam, estão produzindo textos orais, trabalhando a língua em uso real. A noção de que eles sabem que estão trabalhando estruturas linguísticas complexas fica evidente nas falas dos alunos durante a entrevista, como ilustra o trecho a seguir:

Pesquisadora: Você achou interessante participar, expor suas ideias, dar sugestões durante as aulas de língua portuguesa no decorrer do projeto? Por quê?

Aluno: Sim, é importante, nós nos sentimos mais valorizados, motivados. No meu caso, sinto até mais vontade de estudar. Quando o professor fica falando, falando, além da aula não passar, não 
entendemos nada, pois não prestamos atenção, estamos quietos. Isso é, quando ficamos quietos. Porque na maioria das vezes bagunçamos mesmo, e aí não aprendemos nada.

(Resposta do aluno $\mathrm{J}$ ao $2^{\circ}$ questionário).

Esses dados nos mostram o quanto o diálogo entre o professor e aluno é importante na construção do conhecimento, isso está de acordo com as ideias defendidas por teóricos como Freire (1987), Bakhtin (2004), Vigotski (2007), pois para eles só há um verdadeiro aprendizado quando este é construído por meio de um processo dialógico, isto é, no processo de interlocução em torno de conhecimentos a serem adquiridos, os alunos precisam ser vistos como interlocutores, ou seja, como corresponsáveis pela aula, como parceiros.

No que se refere à leitura, observamos que esta ocorreu no decorrer do Projeto Minha Autoria de forma mais significativa para os alunos. Os alunos leram vários contos durante o desenvolvimento do projeto.

Eles precisavam ler, queriam ler, pois entenderam que lendo teriam as informações necessárias para escrever, ou seja, teriam o que dizer, como dizer, além de entenderem melhor a língua, conforme orienta Geraldi (1997) que façamos nas aulas de línguas. Perceberam que o texto não serve apenas para estudo da gramática, que ele diz algo, dialoga com seus leitores, conforme pode ser observado na fala dos alunos na introdução da coletânea de contos a serem lidos em sala, coletânea esta organizada por eles:

O trabalho mostrará contos que nos levam a ver que são histórias totalmente reais, tudo que retrata nesses contos é o que acontece diariamente, são histórias bastante interessantes e nos fazem ver coisas que às vezes não percebemos.

(Texto retirado da introdução da coletânea de contos a serem lidos em sala -6/11/2013)

Os alunos perceberam que a leitura vai além da decodificação das palavras, que ler um texto envolve, fundamentalmente, compreensão, reflexão. Exemplo dessa percepção nos foi apresentado na aula do dia 11/9/2014, na qual foi realizada a leitura do conto "Uma vela para Dario", do escritor Dalton Trevisan. Primeiramente, todos fizeram a leitura silenciosa, depois uma leitura compartilhada em voz alta. Depois disso, as professoras discutiram com os alunos, levantando questionamentos para que estes refletissem, compreendessem o que leram. Os alunos perceberam que, quando escrevemos, queremos dizer algo para nossos 
interlocutores, e que os leitores dão significados ao texto, ou seja, não há apenas um sentido. Isso fica evidente nas anotações do diário de campo:

Durante a discussão os alunos falaram suas interpretações, uma ia complementando a outra e produzindo significados, os instigamos para que relacionassem esse texto com outras leituras, uma aluna disse que o conto mostra a frieza do homem diante do sofrimento do seu semelhante, outro, que isso ocorre diante da correria que vivemos, onde temos que lutar pela sobrevivência, outras que a frieza se deu devido ser comum nas cidades fatos como o que estava sendo abordado no conto, como a indiferença diante do sofrimento do outro, pois Dário estava morrendo sem que as pessoas o ajudassem de fato. Outro aluno aponta que a falta de solidariedade é algo comum no meio urbano. E chegam a conclusão que o autor escreveu esse texto para nos sensibilizar para que possamos refletir diante de nossas atitudes, dos problemas que nos cercam. Percebemos que os alunos se envolveram na discussão, buscando entender o conto, por meio de reflexões. Apenas alguns alunos não participaram ativamente da discussão, se envolveram em conversas, mas não atrapalhou a discussão. Essa atitude é normal em uma sala com mais ou menos 42 alunos.

(Diário de campo, em contexto de leitura e interpretação de texto, no dia 11/9/2013).

Nesse contexto, podemos dizer que é possível realizar um trabalho de leitura que vai além da simples decodificação. Para isso, temos que dar a palavra ao aluno, para que, juntos, através da interação, do diálogo e da colaboração possamos construir e dar significados aos textos lidos.

Observamos também que os alunos liam por prazer, liam em busca de parâmetros para o conto que iriam escrever, o que está de acordo com o que diz Geraldi (1997) quando afirma que o aluno pode ler um texto simplesmente pelo prazer, sem querer escrutiná-lo, ou pode-se ir ao texto em busca de respostas a perguntas que ele tenha, ou em busca de modelos para escrever outros textos. Conforme pode ser observado nas anotações do diário de campo:

Nessa aula colocamos sobre a mesa diversos contos para que os alunos pudessem escolher e realizar a leitura, e posteriormente, organizar a apresentação. Leram nessa aula mais de um conto em busca de um texto ideal para apresentação. Durante a leitura desses contos os alunos sempre compartilhavam com os colegas suas leituras e com as professoras, as quais sempre eram chamadas pelo grupo para esclarecer dúvidas no que se refere a linguagem, a estrutura do texto, quando não entendiam uma palavra, ou quando 
tinha dificuldade de entender o conto, todos estavam envolvidos na atividade e colaborando uns com os outros, trocando informações, ideias sobre o conto lido, que estão lendo e de como vão realizar a apresentação.

(Diário de campo - 8/10/2013).

Isso também pode ser confirmado no relatório produzido pelos alunos sobre a atividade de leitura dos contos para serem apresentados:

Lemos vários contos, quem escolheu este texto que vamos apresentar foi a Ingredi e a Jhenifer, o restante do grupo concordou, resolvemos interpretar e cada um ficar com respectivo personagem, foi a melhor maneira para todos. Com certeza superamos um pouco nossa timidez. Todos se esforçaram e aprendemos o significado de plebiscito, e passamos para o tema. Adoramos trabalhar junto. (Relatório dos alunos - 22/10/2013).

Como sabemos, o trabalho educativo é dinâmico e complexo e é também por isso que a atividade mediadora do professor é muito importante, conforme defendem Freire (1987) e Vigotski (2007). Nos fragmentos acima fica evidente que procuramos criar meios para as práticas de leitura, para que elas ocorressem naturalmente e tivessem um significado ou um objetivo para o aluno. Nesses dados, também fica evidente a colaboração, a troca de informações, de experiências entre alunos e professor, entre alunos e alunos, entre alunos e materiais pedagógicos.

Diante desse contexto, observamos o quanto as interações colaborativas entre os alunos são importantes para o compartilhamento de vivências e, consequentemente, para a aquisição de novas aprendizagens.

Durante o projeto fomos criando estratégias de leitura que motivassem mais e mais a leitura dos alunos. Realizamos várias formas de leitura: silenciosa/autônoma; partilhada/colaborativa e leitura em voz alta. Como exemplo dessas estratégias, podemos citar a aula dia 23/9/2013, na qual foi feita a leitura e discussão do conto "Nhola dos Anjos e a Cheia de Corumbá", do escritor goiano Bernardo Élis.

Antes de realizarmos a leitura, mostramos um vídeo do conto, feito com teatro de fantoches, o qual teve o objetivo de chamar a atenção dos alunos, de despertar a curiosidade deles para a leitura do texto escrito/impresso. Depois, sugerimos que eles realizassem uma leitura silenciosa. A seguir, pedimos que lessem o texto "publicamente", em voz alta, momento em que um aluno representou o narrador e outros três representaram as personagens, a avó, a Nhola dos Anjos, o Quelemente e o menino. 
Depois, realizamos uma leitura partilhada. Nesse momento, cada um lia um trecho e juntos íamos discutindo a linguagem do autor, as escolhas linguísticas e outros elementos da língua, a organização do texto, bem como a temática abordada pelo autor.

Constata-se, nesse contexto, que é importante para nós, professores, criar situações reais de leitura para os alunos, pois dessa forma conseguimos envolver todos eles nesse processo, mesmo aqueles que não têm costume de participar.

Claro, temos que agir como aponta Freire (1996), ou seja, devemos ter ciência de que é possível, numa perspectiva dialógica de educação, manter o rigor científico do ensino, já que isso não implica a ausência de diálogo entre o professor e o aluno. A observação dessa afirmação pode ser detectada a partir das anotações do diário de campo:

Nessa aula, os alunos se envolveram bastante, até aqueles alunos considerados indisciplinados que nunca participaram, falaram da linguagem, do enredo e fizeram alguns questionamentos quanto ao final e que gostaram do vídeo porque ajudou na compreensão do texto e que ficaram curiosos para ler o conto. Nessa aula, retomamos as características textuais (e teóricas) do conto, as quais foram registradas/sistematizadas no quadro com a participação coletiva dos alunos.

A professora lê neste momento (um texto informativo sobre as características do conto, o qual também foi distribuído aos alunos).

Professora: O conto é uma narrativa ficcional. Sua configuração material é pouco extensa...

Professora: Vocês poderiam me dizer se reconhecem no conto lido algumas dessas características?

Aluno 1: Sim, quase todas, é uma narrativa curta...

Aluno 2: número reduzido de personagens, poucas ações...

(Diário de campo - 23/9/2013).

Os fragmentos acima deixam evidente que a aprendizagem deve ocorrer permeada por reflexões que se efetivam por meio de enunciados, uma vez que é através das interações que mudamos ou fortalecemos nossos conhecimentos. Assim, consideramos a sistematização fundamental no processo ensino/aprendizagem. Dessa forma, em muitas das nossas interações e mediações junto aos alunos não deixamos de informar e sistematizar conhecimentos que considerávamos importante que fossem apropriados para que eles pudessem realizar leituras e consequentemente escrever com qualidade. 
Além das práticas de leitura em sala, nossos alunos também realizaram leitura extraclasse, pois organizaram uma coletânea de contos de escritores clássicos, ou seja, fizeram uma lista de quais autores e contos deveriam ler e sistematizaram uma coletânea com a ordem dos autores e contos a serem lidos por todos os alunos do segundo ano A do Ensino Médio. Para fazer a seleção, eles recorreram a vários contos com o objetivo de escolher textos para montagem da coletânea.

Assim sendo, fica evidente que trabalhos realizados por meio de Pedagogia de Projetos promovem a autonomia dos alunos e o professor medeia esse processo orientando, acompanhando. Nuances dessa autonomia podem ser verificadas nas anotações do diário de campo:

Nessa aula, muitos alunos nos procuraram para conversar sobre a organização da coletânea, pediram pra que fôssemos à biblioteca conversar com a bibliotecária e explicar porque eles estavam indo tanto na biblioteca e para emprestar os livros e também pediu que nós tirássemos bastante cópias de contos. Estavam animados e trabalhando em grupo. Nessa aula, assim como em todos os encontros, os alunos sempre mostravam um conto novo que tinham lido.

(Diário de campo - 14/10/2014).

Observamos, nesse período, uma grande procura por livros de contos na biblioteca e também nos sites de busca, quando utilizaram o laboratório de informática da escola. Então, fica evidente que quando se criam estratégias, se motiva, se acompanha, se medeia o trabalho com a leitura, os alunos leem sim. Essa mudança de comportamento também é evidente na fala da aluna:

Para organizar a coletânea tivemos que ler vários contos, lemos Machado de Assis, Cora Coralina, Clarice Lispector e outros. É interessante quanto mais líamos queríamos ler. Gostamos de organizar essa coletânea. Além disso, ajuda no conto que estamos produzindo, dá idéia sabe.

(Resposta da aluna $\mathrm{X}$ ao $2^{\circ}$ questionário).

Ler os contos para apresentar e para montar a coletânea foi bom porque nos ajudou na hora de escrever, não só no modelo, mas de ter o que falar, dizer, entende. Se eu fosse escrever um conto sem ler outros contos não daria conta, ou se fizesse ficaria muito ruim. (Resposta da aluna $\mathrm{Z}$ ao $2^{\circ}$ questionário). 
Esses fragmentos demonstram que a dificuldade dos alunos não está na leitura em si, mas na ausência de significação da mesma. Conforme aponta Geraldi (1997), o aluno só lê se a leitura tiver algum significado para ele. Portanto, cabe à escola criar condições de práticas de leitura, pois essas práticas influenciam no desempenho da produção de texto, uma vez que a atividade de leitura completa a atividade da produção escrita.

Como dissemos, procuramos trabalhar com vários conhecimentos e habilidades no projeto. Assim, criamos várias oportunidades de práticas de oralidade. Nosso trabalho com a oralidade se pautou em registros mais formais da língua, bem como no atendimento a certas convenções sociais exigidas pelas situações do "falar em público". Tudo isso porque sabemos que, em uma situação comunicativa, há normas, por exemplo, para determinar quem fala primeiro, quem pode falar, quem pode interromper, bem como tantas outras restrições, as quais estão intimamente ligadas aos papéis sociais vividos por todo interlocutor em cada situação comunicativa. Exemplo disso é que o ouvinte de uma palestra não se comporta da mesma forma que o ouvinte de uma conversa entre parceiros.

Dessa forma, percebemos que oralidade e escuta estão interligadas, já que não há interação sem ouvinte. Assim, nós, professores, nas atividades de sala de aula, temos que procurar desenvolver nos alunos a competência para saber ouvir o outro, escutar com atenção o que ele tem a dizer, bem como produzir textos orais de acordo com o contexto, exigidos por determinada situação de uso da língua. E, por termos consciência disso, é que durante o projeto trabalhamos a oralidade e a escuta tendo como foco as situações formais de uso da língua, ou seja, a fala formal, mas sem menosprezar as outras variedades da fala.

Os gêneros do discurso oral que procuramos trabalhar no decorrer do projeto foram o debate, a discussão, a exposição de ideias, a explicação, o elogio, a crítica, a defesa de argumentos e a dramatização de contos. A seguir, há o registro de como foi trabalhada a prática oral em sala de aula:

Nessa aula, trabalhamos conto A Cartomante, do escritor Lima Barreto, antes de começar a produção escrita. A professora colaboradora mediou a aula fazendo algumas perguntas sobre o conto lido, tendo como objetivo trabalhar o debate a partir da temática do texto que é a desmistificação do poder das cartas, a farsa que é praticada pela cartomante.

Professora: o que vocês pensam sobre a temática do texto lido?

Professora: Acreditam no poder das cartas?

Aluno 1: Eu não acredito, e o autor deixa isso claro no texto, e isso 
é visível, ou seja, fica claro no final do conto. Deixa eu ler aqui "Entrou, esperou um pouco, com o coração a lhe saltar do peito.O consulente saiu e ele foi afinal à presença da pitonisa. Era sua mulher". É uma farsa as pessoas agem de má fé e pegam o dinheiro das pessoas...

Aluno 2: Também acho que uma forma de ganhar dinheiro fácil, aproveitando do desespero das pessoas, vemos no conto que a personagem (marido) está desesperado diante dos problemas financeiros...

(Diário de campo do dia 23/9/2013, prática da oralidade).

Os fragmentos transcritos do diário de campo representam um momento de prática de oralidade. A partir da leitura dos fragmentos fica evidente que é possível trabalhar textos orais na sala. E isso é importante porque além de darmos a palavra para os nossos alunos, como propõe Paulo Freire (1987), trabalhamos a língua, a oralidade em situação mais formal.

Percebemos que o trabalho de mediação do professor para trabalhar a oralidade de forma que prepare o aluno para usar a linguagem de acordo com seu contexto é muito importante. Nos dados anteriores fica evidente que as professoras criaram estratégias para que o aluno se envolvesse, participasse do debate, pois, para produzir textos, sejam orais ou escritos, o aluno tem de ter o que dizer. E, no exemplo citado, os alunos tinham lido um conto tratando do tema em discussão. Além disso, a professora os instiga por meio de alguns questionamentos para que o debate flua, assim como ocorre em situações da "vida real".

Os dados apresentados demonstram que, para a organização de qualquer atividade que envolva a oralidade, são necessários organização, respeito ao outro que fala e também que saber ouvir é fundamental. Assim sendo, cabe ao professor intervir e direcionar para que o objetivo planejado seja atingido. Isso está ilustrado nos fragmentos acima. Por isso, o professor não pode perder de vista o que foi proposto, garantindo, assim, a aprendizagem do aluno.

Os gêneros do discurso oral, como o debate, a crítica e outros são fundamentais em todo o processo de ensino e aprendizagem, visto que ajudam a sistematizar os pensamentos ao serem verbalizados ou registrados.

A prática desses gêneros demonstrou-nos que as atividades verbais desempenham um papel primordial para ajudar os educadores a retomar as ideias dos contos lidos.

Tivemos também a preocupação de trabalhar os gêneros discursivos orais porque, durante a conversa semiestruturada, na ocasião da exposição do projeto, percebemos que, embora os alunos estivessem cursando o Ensino Médio, eles 
ainda tinham dificuldade em se expressar oralmente e acreditamos que o professor tem fundamental importância para ajudar os alunos a desenvolver a linguagem verbal, que todos nós possuímos, mas que, muitas vezes, é silenciada na escola. Observe uma das intervenções da professora durante a apresentação do conto $\mathrm{O}$ Primeiro Beijo, da escritora Clarice Lispector:

Professora: Pessoal, hoje é a apresentação do primeiro grupo, portanto vamos participar, ouvindo, prestando atenção...

Aluno 1: Professora é para fazer como a senhora orientou, durante a organização da apresentação?

Professora: Sim, fazendo uma pequena introdução do que será apresentado...

Aluno 2: tipo, qual será o conto apresentado, o autor, porque escolhemos esse conto...

(Falas dos alunos em situação de práticas de oralidade - diário de campo, dia 15/10/2013).

Os dados apresentados demonstram que os alunos estavam retomando as orientações dadas pelas professoras aos grupos durante a organização dos contos para apresentação. Os alunos estavam reorganizando suas falas no momento em que iam começar a apresentação, recorrem à professora, mas demonstram saber que seu contexto de fala não pode ser informal, já que o contexto exige uma fala mais elaborada, mais formal.

Portanto, fica evidente que a intervenção das professoras durante o processo de preparação bem como no momento da apresentação é necessária para que os objetivos sejam atingidos.

\section{Considerações finais}

Estamos ainda em fase de seleção de dados para análise. Assim, apresentamos, neste texto, as primeiras impressões sobre o projeto intitulado Projeto Minha Autoria, desenvolvido em uma turma de segundo ano do Ensino Médio de uma escola pública da região Oeste de Goiânia. Objetivamos, ao final da dissertação, descrever e analisar a proposta de ensino Pedagogia de Projetos aplicada ao estudo do gênero discursivo conto. Contudo, o pouco que apresentamos nos permite formular algumas reflexões à guisa de conclusão.

Primeiro, o estudo da língua materna deve ser contextualizado, ou seja, feito por meio do texto e de tudo o que ele representa ou desencadeia, mas o que 
vemos ainda é que o processo de ensino/aprendizagem dessa disciplina se dá pela fragmentação e descontextualização da língua/linguagem. E o mais triste é que essa forma de conduzir o processo de ensino/aprendizagem ainda continua a se repetir na maioria de nossas escolas. Como nossos alunos mostraram, as práticas, no que se refere ao estudo/ensino da língua, eram inadequadas e irrelevantes, não condiziam com as mais recentes concepções de língua, muito menos com os objetivos mais amplos que legitimamente se pode pretender para o seu ensino.

No entanto, sabemos que as dificuldades enfrentadas pelos professores em transformar o estudo/ensino da língua portuguesa a partir da leitura e produção de textos em conteúdo contextualizado na escola não é algo fácil. É importante lembrar que, embora as instituições formais sinalizem/garantam o estudo da língua materna por meio do texto, essas instituições ainda deixam a desejar. Isso ocorre porque elas não explicitam de forma clara os conteúdos a serem trabalhados nem a maneira de se assegurar o estudo/ensino da língua portuguesa por meio da leitura e da produção textual.

Assim, visando compreender o processo de ensino e aprendizagem da língua portuguesa na escola, organizados por meio de projetos, traçamos uma trajetória de trabalho dentro de uma perspectiva dialógica em que as interações, colaborações e mediações realizadas entre professoras e aluno, aluno e aluno, por meio de atividades coletivas, em duplas, em grupo e individuais, demonstram ser excelentes estratégias de ensino da língua materna.

Observamos que o texto mais trabalhado em sala de aula, e de forma maçante, era o artigo de opinião, pois os alunos estavam sendo preparados para o ENEM. Além do artigo de opinião, alguns outros gêneros eram trabalhados, como, por exemplo, o poema. Mas o estudo desses gêneros era realizado superficialmente, sem sentido algum para o aluno. Indagados durante conversa semiestruturada no decorrer da apresentação do projeto, o único gênero que os alunos lembravam que existia era o artigo de opinião. Mas só sabiam o nome (artigo de opinião), por causa do Simulado, o qual ocorria todo bimestre e cobrava esse gênero textual na parte de produção de texto. Alguns gêneros eram "trabalhados" só para cumprir as orientações da Secretaria de Educação, que recomendava para cada bimestre de dois a quatro gêneros a serem trabalhados.

Quanto à produção de textos orais, estes eram quase que inexistentes, já que as aulas de língua portuguesa se restringiam, segundo os alunos, a cópias de conceitos gramaticais e a alguns aspectos dos gêneros artigo de opinião e poema e a conceitos literários. Isso, para alguns professores, é uma estratégia para manter a disciplina e/ou o silêncio em sala de aula, pois, copiando, não sobra tempo para 
conversas paralelas. Em setembro de 2013, modificamos o ritmo das aulas da segunda série A do Ensino Médio, matutino, com a proposta do projeto Minha Autoria.

Com o projeto, as escritas, as reescritas e a revisão dos alunos nos indicaram que as preocupações destes inicialmente centravam-se mais em aspectos relacionados à escrita "correta", ortografia, acentuação, entre outros, do que em elementos relacionados à produção textual. No entanto, durante a realização do projeto Minha Autoria, fomos percebendo com clareza mudanças importantes sobre os conhecimentos que os alunos foram elaborando e reelaborando sobre produção textual e o gênero conto. Percebíamos isso à medida que eles começaram a demonstrar o que aprendiam por meio dos discursos orais e escritos.

Diante disso, as situações vivenciadas por nós, professoras e alunos participantes desse estudo, revelaram que as aprendizagens sobre língua portuguesa, no que se refere aos campos mencionados, pautadas no diálogo, fortaleceram os argumentos e contra-argumentos dos alunos, ajudando-os a elaborar e a construir melhor seus pensamentos bem como as estruturas linguísticas.

O trabalho com a proposta de ensino Pedagogia de Projetos fortaleceu tanto o nosso trabalho como o dos alunos, pois nós todos tomamos consciência dos caminhos que iríamos trilhar, vislumbrando seu início e término.

Os dados nos mostram que, além das mediações ocorridas entre os parceiros: professoras e alunos, alunos e alunos, os instrumentos e materiais de apoio selecionados pelas professoras (livros, dicionários, vídeo, contos e outros) também foram mediadores dos conhecimentos dos alunos. Assim, podemos dizer que as escolhas que nós, professores, fazemos implicam também as aprendizagens dos alunos.

\begin{abstract}
This article discusses the (re)meaning of the learning process teaching in public schools in the light of the proposal of Education Project. Introducing the first time, the historic process of how the surge of Education Project and a second time their contributions to the reality of education within the public school of Goiânia - Goiás, in a report summarizing experience in the classroom. Are the guidance to study concepts such as Education Project, dialogism, banking education, problem-based education, language,
\end{abstract}


speaking/listening, reading, writing, linguistic analysis, gender discourse, which were highlighted in a dialogical approach, based on studies Freire, Bakhtin and Vigotski. The methodology used was the collaborative action research. The analysis shows that students take over the guidance given by teachers to groups during the tasks and are therefore dependent on the effective teaching mediation. Also, it is clear that the intervention of the teachers during the preparation process as well as at the time of verbal production - in its various forms - is necessary so that the objectives are met.

Keywords: Education project. Proposed interdisciplinary. Significant learning.

\section{Referências}

ANTUNES, Irandé. Aula de Português: encontro e interação. São Paulo: Parábola, 2003.

BAKHTIN, Mikhail M. Estética da criação verbal. São Paulo: Martins Fontes, 2003.

BAKHTIN, Mikhail M. Marxismo e Filosofia da Linguagem. São Paulo: Hucitec, 2004. Original publicado em 1929.

BRASIL. Ministério da Educação. Orientações Curriculares para o Ensino Médio: Linguagem, códigos e suas tecnologias. Brasília: Secretaria de Educação Básica, 2006.

BRASIL. Ministério da Educação. Parâmetros Curriculares Nacionais para o Ensino Médio. Linguagens, códigos e suas tecnologias. Brasília: Secretaria da Educação Média e Tecnológica, 1999.

BRASIL. República Federativa do Brasil. Lei no 9.394: Diretrizes e Bases da Educação Nacional. Brasília, 1996.

CRESWELL, John W. Procedimentos qualitativos. In: CRESWELL, John W. Projeto de pesquisa: métodos qualitativos, quantitativos e mistos. 21. ed. Porto Alegre: Artmed/Bookman, 2007. p. 184-210.

DUARTE, A. L. A. A Escola Nova. AMAE Educando, n. 32, 1971.

ESTEBAN, Maria Paz Sandin. Pesquisa qualitativa em educação: fundamentos e tradições. Porto alegre: Artmed, 2010.

FREIRE, Paulo. Pedagogia do oprimido. Rio de Janeiro: Paz e Terra, 1987.

FREIRE, Paulo. Pedagogia da autonomia: saberes necessários à prática 
educativa. São Paulo: Paz e Terra, 1996.

GERALDI, João Wanderley. Linguagem e ensino: exercícios de militância e divulgação. Campinas, SP: Mercado de letras, 1996.

GERALDI, João Wanderley. Portos de Passagem. São Paulo: Martins Fontes, 1997.

GERALDI, João Wanderley. O texto na sala de aula. São Paulo: Editora Ática, 2004.

HERNÁNDEZ, Fernando. Transgressão e mudança na educação: os projetos de trabalho. Porto Alegre: Artes Médicas, 1998.

HERNÁNDEZ, Fernando; VENTURA, Monserrat. A organização do currículo por projetos de trabalho: o conhecimento é um caleidoscópio. Porto Alegre: Artes Médicas, 1998.

JOLIBERT, Josette. A pedagogia por projetos como alavanca para as aprendizagens. In: MICOTTI, Maria Cecília de Oliveira. Leitura e escrita: como aprender com êxito por meio de pedagogia por projetos. São Paulo: Contexto, 2009.

KLEIMAN, Angela B. Texto e leitor: aspectos cognitivos da leitura. Campinas, SP: Pontes, 2010.

LÜDKE, Menga; ANDRÉ, Marli E. D. A. Pesquisa em educação: abordagens qualitativas. São Paulo, SP: EPU, 1986.

MACHADO, Irene. Inacabamento como modelo artístico de mundo. Disponível em: $\quad<$ http://revistas.pucsp.br/index.php/bakhtiniana/article/view/3372/2242>. Acesso em: 17 ago. 2013.

MATENCIO, Maria de Lourdes Meirelles. Leitura, produção de textos e a escola: reflexões sobre o processo de letramento. Campinas, SP; Mercado de Letras, 1994.

MICOTTI, Maria Cecília de Oliveira. Leitura e escrita: como aprender com êxito por meio de pedagogia por projetos. São Paulo: Contexto, 2009.

MOREIRA, Herivelto; CALEFFE, Luiz Gonzaga. Metodologia científica para o professor pesquisador. Rio de janeiro: Lamparina, 2008.

PENTEADO, Heloísa Dupas. A relação docência/ciência sob a perspectiva da pesquisa-ação. In: PENTEADO, Heloísa Dupas; GARRIDO, Elsa. Pesquisaação: a comunicação escolar na formação do professor. São Paulo: Paulinas, 2010. p. 21-31. 
ROJO, Roxane (Org.). A prática de linguagem em sala: praticando os PCNs. SP: Educ; Campinas, SP: Mercado de Letras, 2000.

THIOLLENT, Michel. Metodologia da pesquisa-ação. 13. ed. São Paulo. Metodologia da pesquisa-ação. 13. ed. São Paulo: Cortez, 2004.

VIGOTSKI, Lev Semenovich. A formação social da mente. São Paulo: Martins Fontes, 2007.

VIGOTSKI, Lev Semenovich. Pensamento e linguagem. São Paulo: Martins Fontes, 2008.

Submetido em: 27 de abril de 2015. Aceito para publicação em: 02 de outubro de 2015. 